\title{
Türk İslam Edebiyatında Faziletnameler ve Mekke, Medine, Kudüs, Şam Üzerine Yazılmış Manzum Bir Faziletname
}

\begin{abstract}
Kübra Y1lmaz ${ }^{1}$
Öz

Türk edebiyatında "Faziletnâme" adı altında, edebî bir tür olarak gruplandırabileceğimiz ve şimdiye kadar bütünüyle üzerinde durulmamış manzum/mensur, telif/tercüme pek çok eser mevcuttur. Bu çalışma Mekke-i Mükerreme mücaviri ve Hicaz mütercimi Abdurrahman Şevkî (XIX. yy.)'nin Teşvîku'l-Müsstâk ve Teşrîkun li'l-'Uşşâk isimli manzum şehir faziletnâmesinden hareketle hazırlanmıştır. Eser Mekke, Medine, Kudüs ve Şam'ın faziletlerini ve önemini anlatmaktadır. Şehir faziletnâmeleri, ikâmet edilen yerlerin maddî-manevî özelliklerinin veya ilmî, dinî (hac-umre) seyahatler vesilesiyle bir yerin gezilip görülmesi sonucu edinilen izlenimlerin anlatıldığı eserlerdir. Şehir faziletnâmeleri bazen bir muhîtin tarihî, kültürel, sosyal ve ekonomik durumunu resmeden; bazen de yalnızca fiziksel özelliklerini anlatan bir tür olma niteliği taşırlar. $\mathrm{Bu}$ çalışmada öncelikle faziletnâme ve özellikle şehir faziletnâmeleri üzerinde durulmuştur. Ardından da yukarıda ismi zikredilen Teşvîku'l-Müsstâk ve Teşrîkun li'l- 'Uşş̧âk tanıtılmıştır.
\end{abstract}

Anahtar kelimeler: Faziletnâme, şehir, Abdurrahman Şevki.

\begin{abstract}
There are so many original or translated literary works that we can group under the title "Faziletnameler". This genre has been understudied. This dissertation examines Tesviku'l-Mustak ve Tesrikun lil-Ussak, a city faziletname by Abdurrahman Sevki (XIX century) who resided in the Holy City of Mecca and worked as a translator for the Hejaz region. Sevki's work talks about the importance and virtues of Mecca, Madina, al-Quds, and Damascus. City faziletnames are literary works that narrate experiences and describe physical and spiritual features of places that authors resided in or traveled to for academic or religious purposes. Faziletnames sometimes portray historical, cultural, social and economic characteristics of a place and sometimes they only describe physical features of the places. This dissertation starts with reviewing faziletnames and especially focuses on city faziletnames. Lastly, it introduces the aforementioned work, Tesviku'lMustak ve Tesrikun lil-Ussak.
\end{abstract}

Key Words: Faziletname, city, Abdurrahman Şevki

\footnotetext{
${ }^{1}$ Arş. Gör., Erciyes Üniversitesi, İlahiyat Fakültesi, İslam Tarihi ve Sanatları Bölümü, Türk İslam Edebiyatı
} ABD, kubrapolat@erciyes.edu.tr

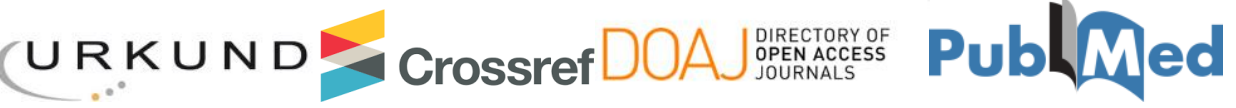




\section{Giriş: Faziletnâme}

Türk İslâm edebiyatı sahasında ortaya konan eserleri türlerine göre "Cenâb-1 Hakk'a dâir olanlar", "Hz. Peygamber'i anlatanlar" ve "diğer meseleler üzerine yazılmış eserler" olmak üzere üç genel başlık altında toplamak mümkündür. İslâmî edebiyatlarda, bu ilk iki başlık altında pek çok eser verildiği ve araştırmaların genellikle ilgili konular üzerinde yoğunlaştığ1 görülmektedir. Bununla birlikte, oldukça kapsamlı "diğer türler" sınıfında henüz temas edilmemiş hususlar mevcuttur. Bu çalışma Türk İslâm edebiyatı sahasının diğer türlerinden biri kabul edilen faziletnâme ve özellikle şehir faziletnâmeleri üzerinedir.

Fazîlet, sözlüklerde "artmak, fazlalaşmak, meziyetli ve üstün olmak" anlamlarına gelen, Arapça fazl (فضل) kökünden türemiş bir kelimedir. İyilik, lütuf, ihsan ve sevabı bol amel mânâlarında da kullanılan faziletin çoğulu (فضائل) fezâildir. Fezâil ismi, kişide iyilik yapmaya yönelik vasıfların bulunması ve erdem bakımından diğerlerinden üstün olma; iyilikte yüksek derecede bulunma, meziyet; insanın yaratılışındaki bütün iyi huylar gibi anlamları ihtivâ etmektedir (İbn Manzûr 1997, X: 280-282; Zebîdî 1306, VIII: 61-62; Râğıb el-İsfahânî 2002， II: 639; İsfahânî fazl kelimesininin, övülen (ilmin ve hilmin artması gibi) ve yerilen (öfkenin artması gibi) türden "ziyâdelik"leri ifâdede kullanıldığını söylemektedir. Ayrıca “fazl'ın "üstün olmak" anlamında kullanıldığı zaman, "cins" (hayvanların bitkilere üstünlüğü gibi), "tür" (insanın hayvandan üstünlüğünde olduğu gibi) ve "zât" (bir insanın başka bir insandan üstün oluşu gibi) üstünlüğü şeklinde üç kısma ayrılması gerektiğini söylemiştir).
Edebî bir terim olarak faziletnâme, Arapça "fazîlet" ile Farsça "mektup, kitap veya dergi"ye karş1lı gelen "nâme" kelimesinin terkibiyle "üstünlükleri medhetmek için yazılmış kitap yahut risâle" anlamına bürünmüştür.

Kur'ân-1 Kerîm ve hadislerde sıkça karşılaşılan fazl kelimesi ile fażîlet, feżâil, ef̣̣al gibi türemişleri, yaptı̆̆ iyi davranışlara karşıllk Cenâb-1 Hakk'ın kuluna bahşettiği lütuf ve ihsanı ifade ederler. Ayrıca bireyin erdemli ve ahlâken üstün olma durumunu belirtmek için de bu kavramlar kullanılmaktadır. Feżale fiilinin "feżżale, feżżaltüküm, feżżaleküm, feżżalnâ, feżżalenâ, feżżalnâhüm, nufażżilu, fużżilû, yetefeżżale, el-Fażl, fażlen, fażlihi, tafżîlen" gibi iştikakları 34 surede, toplam 92 ayette geçmektedir (bk. Abdülbâki 2001. Ayetlerde yer alan bu kelimeler Allah'ın çeşitli hususlarda "birilerini birilerinden üstün kılması" (en-Nisâ 4/34; en-Nahl 16/71); "lütfu, bol nimeti" (en-Nisâ 4/ 95; el-İsrâ 17/12) ile "O'ndan gelen zafer, iyilik" (elBakara 2/105; Âl-i İmrân 3/152) ve "birilerinin birilerine üstünlük taslaması" (elMü'minûn 23/24) biçimlerinde tefsir edilirler).

Hadis-i şeriflerde de sıkça karşımıza çıkan fazl ve müsstakları, genellikle "Allah'ın lütfu ve ihsanı", "sizin en faziletliniz" ve "en faziletli davranış" şeklinde başlayan bu rivayetlerde ahlâkî erdem, üstünlük vb. anlamlarla yer almıştır (Örnek için bk. Buhârî, "İmân", 18, "Fezâ'ilü'l-Kur'ân", 17; "Fezâ'ilü’s-Sahâbe"; “Fezâ'ilü'l-cihâd", 1; İbn Mâce, "Mesâcid ve'l-Cemâ'at", 16; Ebu Dâvûd, "Cihâd", 7; "Salât", 48). 
Klâsik hadis kaynaklarında, özellikle "Fezâilü'l-Kur'ân" adıyla müstakil bölümler bulunmaktadır. İlk dönem hadis kaynaklarında (Kütüb-i sitte) ve daha sonralar1 da Müstedrek, Câmi'u'l-Usûl ve Kenzü'l-Ummâl'de ve özellikle bu sonuncu eserde "Fezâilü'l-Kur'ân" bölümünün genişliği dikkat çekmektedir. Bu eserde sure ve ayetlerin faziletiyle ilgili çok miktarda sahih, zayif ve mevzu rivayetin bir arada olduğu görülmektedir. Kur'an'ın faziletleriyle ilgili bu hadislerin bir kısm1 Kur'an'ın tamamının, bir kısmı da bazı sure ve ayetlerin faziletlerine dâirdir (Sancaklı 2001: 133). Yine bu hadis kaynaklarına bakıldığında fezâil bölümlerinin "Fezâilü'1Kur'an"dan başka, şu konular üzerine tasnif edilmiş rivayetlerden oluştuğu görülmüştür: "Peygamberlerin faziletleri”, "Resûlullah'in faziletleri", "Ashâbın faziletleri", "İslâm ümmetinin faziletleri", "Muhtelif millet ve kabilelerin faziletleri", "Bazı vakitlerin ve mekânların faziletleri", "Bazı amellerin ve duâların faziletleri”, "Hastalık, ölüm ve musibetlerin faziletleri”.

Fazilet kavramı öncelikle Arap edebiyatında amellerin, zamanların, şahısların, kabilelerin, milletlerin, yer ve şehirlerin, benzerlerinden üstünlügünü anlatmak için kullanılmış ve bu konuların her birine dâir kitap ve risâleler yazılmıştır. Bunların başında çoğu zaman hem tür ve hem de müstakil eser adı olarak kullanılan Fezâilü'l-Kur'ân (örn. en-Nesefî Müstagfirî, Fezâ'ilü'l-Kur'ân), Hasâis veya Hasâisü'n-Nebî (örn. İbnu'l-Haydırî, elLafzü'l-Mükerrem bi-Hasâ'isi'n-Nebiyyi'lMu'azzam), Fezâilü's-Sahâbe (örn. Ahmed b. Hanbel, Fezâ'ilü's-Sahâbe), Fezâilü'l-A'mâl (örn. el-Makdisî, Fezâ'ilü'l-A'mâl), Fezâilü'l-Evkât (örn. Beyhâkî, Fezâ'ilü'lEvkât) gelmektedir. Ayrıca Fezâ'ilü Mekke, Fezâ'ilü Medine gibi dinî ve siyâsî bakımdan önemli mekânların faziletlerini, Fezâ'ilü'lEtrâk (bk. el-Câhız, Fezâ'ilü'l-Etrâk) gibi bir milletin üstün vasıflarını veya Fezâ'ilü'l-
Kitâb (örn. Muhammed İs'irdî, Fezâ'ilü'lKitâbi'l-Câmi' li-Ebî Îsâ et-Tirmizîl) gibi bir kitabın faziletlerini anlatan eserler kaleme alınmıştır.

Ayet-i kerime ve hadis-i şeriflerle medhedilen sahâbelerin, dört büyük halifenin veya ehli beytin faziletleri ile ilgili müstakil eserler yazıldığı gibi; kimi zaman da çeşitli eserler içerisinde onların övgüsüne has bölümler kaleme alınmıştır. Dört halifenin faziletleriyle ilgili Türkçe edebî eserlere Kerderli Mahmud bin Ali (v.761/1360) tarafından Harezm Türkçesi ile yazılan Nehcü'l-Ferâdis (Cennetlerin Açık Yolu)'in bir bölümü örnek gösterilebilir. Eser dört ana bölümden ve her bölüm de on fasıldan ibaret olmak üzere toplam kırk fasıldan oluşmaktadır. Her faslın başında bir hadis bulunmaktadır. Eserin konumuzla ilgili olan ikinci bölümü dört halife, ehl-i beyt ve dört mezhep imamının faziletlerini ele almaktadır (Y1lmaz 2011: 24).

Edebiyatımızda, türler üzerine bilinen en eski tasnif Agâh Sırrı Levend'in Türk Edebiyatı Tarihi'nde yer almaktadir. Levend bu tasnifte faziletnâmeye yer vermemiştir (Ayrıntılı bilgi için bk. Levend 1973). Tespit edebildiğimiz kadarıyla türe ilk kez temas eden Âmil Çelebioğlu, faziletname hakkında şu tespitlerde bulunmuştur:

"İslâmî edebiyatta "Fazîlet-nâmeler"
umumî adı altında edebî bir nev'i
olarak gruplandırabileceğimiz ve
şimdiye kadar bütünüyle üzerinde
durulmamıs bir hayli eser mevcuttur.
Hemen her mevzuda manzum veya
mensur olarak çeşitli faziletnâmeler,
te'lif veya tercüme olarak kaleme
alınmıstır. İçlerinde gerçekten edebî
kıymeti hâiz olanlar çoktur. Bunlar
mevzularına ve şekillerine göre tasnif
edilip incelendikçe bilhassa İlâmî̀
Türk edebiyatındaki edebî nev'ilerin
veşiìr mevzulanının sanıldığından daha


fazla olduğu $b u$ vesile ile de görülecektir. Manzum veya mensur, kücük veya büyük hacimde karşılaş̧ı̆ı̆mız faziletnâme tipindeki eserler, çok kere isimleriyle nev'ilerini ve muhtevalanını belirttiği gibi değişik bir adla da karşımıza çıkmaktadır. Fazîletnâmeler İslâm âleminin mukaddes şehirlerinin faziletine, tarihine ve çeşitli hususiyetlerine dâir olabilirler; Fezâilü'l-Mekke, Fezâilü Mekke ve'l-Medine ve'l-Kuds, Fezâil-i Haremeyn-i Şerifeyn, Fezâil-i Misr, Fezâil-i Şam vs. gibi veya Fezâli-i Mescid-i Aksâ, Fezâil-i Hulefâ-i Râşidîn, Fezâil-i Hazret-i Ali, Fezâil-i Kureyş, Fezâilü'l-etrâk gibi mabed, halife, şahıs ve milletlerin fazilet ve hususiyetine dâirdir. Yahut da Fezâil-i Kur'an, Fezâilü'l-cihâd ${ }^{1}$, Fezâilü'lezkâr, Fezâilü'ş-şuhûr, Fezâil-i Ramazân, Fezâilü's-siyâm gibi değişik mevzulardadır." (Çelebioğlu 1971, X: 342-343).

Âmil Çelebioğlu tür tasnifi yaparken "muhtelif konulardaki bazı mesneviler ve manzum eserler" başlığı altında "Dinî, tasavvufî, ahlakî, tarihî, aşk ve macera türündeki eserlerin konuları ile kısmen alâkalı veya tamamen farklı konularda; tespiti hiç de kolay olmayacak kadar çok isim ve eserle karşılaşmak mümkündür" diyerek fazîletnâmeler, şsehrengizler, sûrnâmeler, sâkînâmeler ve manzum lügatleri, tespiti hiç de kolay olmayacak bu eserlere örnek gösterir. Ayrıca Hafizoğlu Muhammed Yemînî’nin, yedi bin küsür beyitli mesnevi tarzındaki Fazîletnâme'sinin, Hz. Ali'nin fazîletleriyle ilgili olup, 925/1519 tarihinde nazmolunduğu bilgisini ekler (Çelebioğlu 1994: 104-105).

\footnotetext{
1 bk. Fezâ'ilü'l-Cihâd (bk. Dadaş 1995) Bilindiği kadarıla, İslâm askerlerini kâfirlerle cihada teşvik için yazılmış olan Fezâ'il-i Cihâd Ahmed b. İbrahim'in Meşâ'irü'l-Eşvâk ilâ-Mesâ'iri'l- 'Uşşâk isimli Arapça eserinden Türkçeye tercüme edilmiş olup yazıldığ devirde kışlalarda çok okunan bir eser hâlini almıştır.
}

Abdurrahman Güzel, Dinî-Tasavvufí Türk Edebiyatı adlı kitabında faziletnâme başlığı altında Hafızoğlu Derviş Muhammed Yemînî'nin, 1519'da yazdığı ve geneli itibariyle Hz. Ali'nin biyografisini ele alan Fazîletnâme-i Yemînî sinden (Güzel 2006: 708-709; Aça vd 2009. Eserle ilgili çalışmalar için bk. Tepeli 2002; Kırman 2004) örnek metin vererek konuyu, sadece "şahıs faziletnâmeleri" doğrultusunda izah etmiştir. Ayrıca araştırmalarımız esnasında Muhammed Yemenî’ye ait olduğu belirtilen Fezâ'ilü Mekke ve'l-Medîne ve'l-Kudsü Şerîf adlı bir eser üzerine yapılmış iki adet yüksek lisans tezine ulaştık (Eserle ilgili çalışmalar için bk. Aydın 1987; Yıldırım 2010). Bu tezlerde adı geçen Muhammed Yemenî ve onunla aynı asırda yaşamış Derviş Muhammed Yemînî'nin aralarında bir irtibat olup olmadığ 1 bilinmemektedir. Bilindiği kadarıyla Yemînî'nin Fazîletnâme'den başka eseri yoktur. Dolayisiyla bu iki tez çalışmasında adı geçen Muhammed Yemenî ya başka biri olmalıdır yahut Derviş Muhammed Yemînî adiyla meşhur bu zâtın bir de Fezâ'il-i Mekke ve'l-Medîne ve'lKudsü Şerîf adlı bir eseri daha bulunmaktadır. Üç bâb altında toplam otuz fasıldan oluşan ve sırasıyla Mekke, Medine ve Şam'ın faziletlerini anlatan Fezâ'ilü Mekke ve'l-Medîne ve'l-Kudsü Şerîf adlı bu mensur Türkçe eser de faziletname türüne örneklik etmesi bakımından önemli sayılmaktadır (Muhammed b. el-Yemenî adına kayıtlı içeriği aynı fakat ismi farklı şu elyazmalarına Süleymaniye kütüphanesi kataloglarında rastlanmıştır; Tuhfetü'l-âşıkîn fî fedâ'il-i Mekke ve'l-Medine ve'l-Kuds, 134 vr., Süleymaniye Kütüphanesi, A. Tekelioğlu, nr. 796-1; Fedâ'ilu Mekke ve'lMedine ve Beyti'l-Makdis, 145 vr., Süleymaniye Kütüphanesi, Ayasofya, nr. 3341; İmam Muhammed el-Gazâli Yemenî, Risâle fî fezâ'il-i Mekke ve'l-Medine ve'lKuds, 111 vr., Süleymaniye Kütüphanesi, Esad Efendi, nr. 2339). 
Bâkî'nin Fezâ'il-i Mekke'si bir başka mühim faziletnamedir (Fezâ'ilü Mekke adıyla meşhur eser genellikle el-I'lâm bi-a'lâmi beledillâhi'l-harâm tercemesi adıla kayıtlıdır. Süleymaniye Ktp. Hekimoğlu, nr. 719; Aşir Efendi, nr. 231; Ayasofya, nr. 3091; Bağdatlı Vehbi, nr. 1311-002; Damad İbrahim, nr. 890; Esad Efendi, nr. 1826; Fatih, nr. 4258, 4259, 4187; H. Hüsnü Paşa, nr. 872; Hac1 Beşir Ağa, nr. 464). Eser Muhammed b. Ahmed Kutbuddin elMekki(v.1582)'ye ait el-I'lâm bi-a'lâmi beledillâhi'l-Harâm adlı eserin Türkçeye mensur tercümesidir. Tercüme Fezailü Mekke adiyla da bilinmektedir. İlk bab Mekke-i Müsserrefe 'nin vaz' u hey'eti, ikinci bab Ka'be-i Muazzama'nın binâsı, üçüncü bab vaz'-1 Mescid-i Harâm'ın eyyâm-1 Cahiliye'de ve sadr-1 İslâm'daki ahvâli üzerinedir. Beşinci bab Mescid-i Harâm'in terbiinden sonra vâki' olan ziyâdeler beyânındadır. Bâkî bu çalışmayı Mekke kadılığı yaptığı 1570'li yıllarda hazırlamıştır. Mekke tarihinden ve Osmanlı padişahlarının Mekke'de yaptırdığı eserlerden söz eden bu kitabin Sultan III. Murad'1 (v. 1595) ve Sokullu'yu (v. 1579) öven başlangıç kısmı musannâ, kalanı sade bir Türkçe ile yazılmıştır (Tergip 2010: 42-43). Kütüphanelerimizde çok sayıda nüshası bulunan bu eser henüz neşredilmemiştir.

Türk edebiyatında faziletnâmelere verilecek bir diğer örnek Hıfzî adına kayıtlı 1265 tarihli ve yaklaşık 50 varaklı Târîh ve fezâ'il-i Kuds-i Şerif adlı mensur eserdir. Eserin kütüphanelerimizde yazma ve matbu nüshaları mevcuttur (Hıfzî, Tarîh ve fezâ'il-i Kuds-i Şerif, Bayezid Devlet Ktp., nr. 5071; Hifzî, 1265).
Şehir faziletnâmelerinin yazılma sebepleri arasında ilk sırayı Kur'an, hadis ve ashâb ile tâbiînin sözlerinde bazı özel şehirlerin zikredilmesi alır. İslâm tarihinde sirasıyla en çok Mekke, Medine, Kudüs, Dımaşk (Şam), Kûfe, Bağdat, Basra, Belh, Endülüs ve Yemen şehirleri ile bunların faziletleri hakkında kitaplar yazılmıştır. Ayrıca önemli addedilen bu şehirlerde doğmuş, yaşamış ve/veya yetişmiş enbiyâ ve evliyanın övgüsü de faziletname yazımını teşvik edici unsurlarındandır. Bunun yanısıra özellikle Araplarda, milliyetçilik şuurunun tahriki sebebiyle çeşitli millet, memleket, şehir ve kabileler hakkında Hz. Muhammed'in dilinden pek çok medih ve yergi rivayet edilmiştir. Bilhassa şehir faziletleri üzerine mevzu hadis derlemeleri oluşturacak kadar çok malzeme bulunmaktadır (Kandemir 1991: 50; Kandemir 1995: 529-531).

Bununla birlikte zaman içerisinde elbette İslâm tarihi açısından önemli ve gerçekten Hz. Peygamber'in övgüsüne mazhar olmuş bazı şehirler hakkındaki rivayetlerin toplandığı eserler de yazılmıştır (bk. Rıfâî 1992; Ahsasî 2006).

Bir şehrin faziletine dâir yazılan ilk eserin Hasan-1 Basrî'ye (v. 110/728) nispet edilen Fezâ'ilü Mekke olduğu tahmin edilmektedir. İlk örneklerini Arap edebiyatında gördüğümüz şehir faziletnâmelerinin 74 adedini müellif ismi ve yüzyılları ile beraber Salâhuddîn el-Müneccid Fezâ'ilü'l-Endelüs ve ehlihâ'nın mukaddimesinde vermektedir (bk. İbn Hazm, 1968, mukaddime).

Yine şehir tarihi ve coğrafyası üzerine yazılmış bazı eserlerde de ilgili ülkenin, şehrin veya muhitin özelliklerini anlatan bir fezâil bahsine rastlamak tabiidir (Ayrıntılı bilgi için bk. Şeşen 1998: mukaddime). 
Faziletnâmeler hakkındaki bu araştırma çerçevesinde, Süleymaniye Kütüphanesi kataloglarında, isminde "fazl, fazilet, fezâil" kelimelerinin geçtiği ve tür kapsamında kabul edilebileceğini düşündüğümüz eserleri tespit ederek sınıflandırdık. Arapça fezâil kitapları ve risâleleri ile Farsça yazılmış eserlerin de dâhil edildiği bu tasnif neticesinde fezâil konularının oldukça geniş bir alana yayıldığı ve ahlâk, tarih, hadis, tefsir vb. pek çok ilme dâir eserlerle ortak çerçevede yer aldığ görülmüştür. $\mathrm{Bu}$ eserler muhtevâlarına göre genel olarak "şehir ve ülkelerin faziletleri", "cihadın faziletleri”, "Kur'ân-1 Kerim ve bazı surelerin faziletleri", "şahıs ve milletlerin faziletleri", "bazı zikir ve evradın faziletleri", "bazı kutlu vakitlerin ve ayların faziletleri", "ibadet, ahlak ve amellerin fazileti" ve "bazı müstakil konularda yazılmış faziletnâmeler" olmak üzere sekiz genel başlık altında toplanmaya çalışılmıştır.

İsminde "fazl" veya "fazl"dan türemiş kelimeler geçmediği halde bir şehrin diğerlerinden üstünlüğünü vasfeden fezâil kitaplar1 mevcuttur. $\mathrm{Bu}$ özel isimlendirmelerden biri Teşvîku'l-müştâk ve teşrîkun li'l-'uşşâk (Abdurrahman Şevkî, Teşvîku'l-müsstâk ve teşrîkun li'l-uşşâk, Millet Kütüphanesi, Ali Emîrî, Manzum, nr. 865, 866)tır. Teşvîku'l-müsstâk ve teşrîkun li'l-'uşşâk ismi, eserin fezâil kitabı olduğuna dâir herhangi bir ipucu vermemektedir. "Özleyenleri şevklendirme, harekete geçirme (Teşvîku'l-müştâk)" ve "âşıkları nurlandırma (Teşrîkun li'l-'uşşâk)" mânâlarına gelen iki Arapça ibareden oluşan isim, eseri okuyanların kutsal beldelere olan iştiyakını artırma maksadına vurgu yapmaktadır.

\section{Müellif Hakkında}

Müellif Abdurrahman Şevkî hakkında yeterli ve net bilgimiz yoktur. Eserlerinin telif tarihinden yola çıkılarak XIX. yüzyılda yaşamış olduğu söylenebilir. Şevkî mahlaslı şâirin Teşviku'l-Müştâk ve Teşrikun li'l'UŞşâk adlı eserinin incelediğimiz iki nüshasında da "el-Ereglevî" (الاركلوى) şeklinde okunabilen nisbesi dişında kendisiyle ilgili bir bilgi bulunmamaktadır.

Bunun yanı sira müellife ait olan ve aşağıda mukaddimesinden bir bölümünü alıntıladığımız bir başka eserde geçen "elKonevî" lafżından hareketle Şevkî'nin Konya Ereğlisi'nden olduğunu iddia edebiliriz. Terceme-i Hadîkati'l-Enâm fî-Fezâ'ili 'ş-Şâm isimli bu kitabın mukaddimesindeki ilgili kısım şöyledir:

“...emmâ ba'd ma'lûm ola ki Şâm-1 Şerîf 'ulemâ-1 kirâmindan Sinâniye câmic $i$ șerîfi haţîbi fazî̀letlü șeyh 'Abdurrahmân Efendi bin 'Abdurrezzâk, ed-Dımaş̧̧̄̄n'niň 1130 țârîhinde te'lif idüp Hadîkatu'l-Enâm fi-Feżâ'ili'ş-Şâm tesmiye eyledigi 'Arabiyyu'l-'ibâre kitâb-1 müstețâbin̆ lisân-ı Türkî'ye terceme olunması işbu 1295 sene-i hicriyyesinde ba' ${ }^{\prime} 1$ żevât-1 kirâm işbu faķīe ya'ni Mekke-i Mükerreme mücâviri ve Hicaz vilâyeti mütercimi 'Abdurraḥmân eş-Şevkī elKonevî ed-Dımaş, hì hakīire emr u tenbîh eylemeleri üzerine vüs'-i 'âcizânem miķdârı terceme eyledim." (Terceme-i Hadîkati'l-Enâm fi-Fezâ'ili'ş-Şâm, trc. Abdurrahman Şevkî, Millet Ktp., Tarih, nr. 905, $1^{\mathrm{b}}$.)

\footnotetext{
2“Ereğli” ismi Anadolu'da dört farklı şehrin sınırları içinde yer alan bölgeler için kullanılmıştır. Bu bölgeler şunlardır: 1. (Konya Ereğlisi): Kaza/ Aksaray, Konya Vilâyeti, 2. (Karadeniz Ereğlisi): Kaza/ Bolu, Kastamonu, Zonguldak, 3. (Marmara Ereğlisi): Kaza/ Çorlu, Tekirdağ, Edirne, 4. (Güzelyalı, Güzelkıyı): Köy/ Merkez- Karamürsel-Kocaeli; ayrıntılı bilgi için bk. Sezen 2006: 173- 174.
} 
Bu mukaddimeden, Terceme-i Hadîkati'lEnâm fî-Fezâ'ili'ş-Şâm'1 hazırlayan elKonevî ed-Dımeşkî nisbeli müellifin Mekke-i Mükerreme'ye mücavir olarak yaşadığ 1 ve Hicaz vilâyetinde de mütercimlik vazifesini ifa ettiği anlaşılmaktadır. Aynı eserin sonunda Abdurrahman Şevkî kendisini "elmütercimü'l-hakîr" olarak vasfetmiştir.

Abdurrahman Şevkî'nin Teşvîku'l-Müştâk ve Teşrîkun li'l-'Uşşâk' tan başka iki eseri bilinmektedir:

\section{Teşvîku'l-Müştâk ve Teşrîkun li'l-'Uşşâak.} Eser ilerde ayrıntılı olarak incelenecektir.

Terceme-i Hadîkati'l-Enâm fi-Fezâ'ili'şŞâm: Abdurrahman b. Abdürrezzak edDımaşkî'nin 1130 tarihinde telif ettiği Hadâ'iku'l-İn'âm fí-Fezâ'ili'ş-Şâm adlı mensur eserin Terceme-i Hadîkati'l-Enâm fíFezâ'ili'ş-Şâm ismiyle Abdurrahman Şevkî tarafindan 7 Şevval 1295/5 Ekim 1878 tarihinde Türkçeye tercüme edilmiştir (Terceme-i Hadîkati'l-Enâm fi-Fezâ'ili'şŞâm, trc. Abdurrahman Şevkî, Millet Ktp., Tarih, nr. 905).

Millet Kütüphanesi'nde tespit edebildiğimiz ve rik'a hattıyla yazılmış bu tek nüsha eser 131 varaktan oluşmaktadır. $\mathrm{Bu}$ nüshanın istinsah tarihi ise 29 Şevval 1303/31 Temmuz 1886'dır.

Araştırmamız çerçevesinde Hadâ'iku'l-İn 'âm fî-Fezâ'ili'ş-Şâm ismiyle bu eserin tahkikine ulaştık. Abdürrezzak ed-Dımaşkî'nin bu kitabı Yusuf Bedîvî tarafından Hadâ'iku'lIn 'âm fî-Fezâ'ili' ş-Şâm adıyla neşredilmiştir. Görüldüğü üzere eserin adı, tercümesinde ve tahkikinde farkl1lik göstermektedir. Abdurrahman Şevkî tarafından yapılmış tercümesinin mukaddimesine göre Hadâ'iku'l-İn 'âm fi-Fezâ'ili'ş-Şâm 'in müellifi Abdurrahman b. Abdürrezzak edDımaşkî Şam'daki Sinâniye Camii'nin hatipliğini yapmıştır. 1187 'de vefat etmiş olan bu şahıs hakkında ayrıntılı bilgi eserin neşrinde verilmektedir (bk. Abdurrahman b. İbrâhim b. Ahmed ed-Dımaşkî el-Hanefî İbn Abdürrezzâk, Hadâikü'l-İn'âm fî-Fezâ'ili'şŞâm, 1138/1726, thk. Yusuf Bedivî, Dımaşk, 1995).

8 bâb olan tercümenin birinci bâbında Şam bölgesinin hudutları, ikinci ve üçüncü bâbında Şâm'ın fezâili hakkındaki hadis rivayetleri, dördüncü bâbında Şam'a dair seleften naklolunan sözler, beşinci, altıncı ve yedinci bâblarında Şam'ın meşhurları ve Dımaşk civarındaki enbiyâ, ashâb ve tâbiinin kabirleri ve sekizinci bâbında Şam'ın güzellikleri anlatılmıştır.

Araştırmamızın asıl konusu olan Teşvîku'lMüstâk ve Teşrîkun li'l-uşşâk' taki bazı manzumeler Terceme-i Hadîkati'l-Enâm fîFezâ'ili'ş-Şâm'da da "Nazm li'l-Mütercim" başlığıyla yer almaktadır. Ayrıca bu iki eser arasında aynı ayetlerin, aynı hadislerin, aynı tarihî hadise ve şahsiyetlerin yer alması gibi pek çok benzerlik görülmektedir.

\section{Terceme-i Risâle-i Tarîkat-1 Âliyye:} Almanya Milli Kütüphanesi (Berlin) Türkçe yazmalar1 bölümünde (nr. Hs.or.oct.911 Staatsbibliothek) Abdurrahman Şevkî adına kayıtllı olan Terceme-i Risâle-i Tarîkat-1 Âliyye hakkında kesin bilgimiz yoktur. Tâhir isimli müstensih tarafından rik'a hattiyla istinsah edilen eserin bir mecmuanın 3. risâlesi olduğu bilinmektedir. Mecmuanın 5968. yaprakları arasında yer alan risâle hakkındaki bu bilgiler bizzat doğrulanmamıștır (Kültür ve Turizm Bakanlığı kataloğu:

https://www.yazmalar.gov.tr/detay goster.ph $\mathrm{p} ? \mathrm{k}=124900,16.02 .2017$ tarihli erişim). 
Teşvîku'l-Müştâk ve Teşrîkun li'l-'Uşşâk'in Nüsha Tavsifi

Millet Kütüphanesi, Ali Emîrî Manzum, nr. 865:

Başı:

$1^{\text {b }}$ el-Hamdu li'llâhi'llezî zâde Mescide'lAkșâ şerefen lâ-siyyemâ bi-ḳudûmihi ileyhi Seyyidü'l-ḩalḳi ve'l-beşer... şeklinde mensur bir mukaddime ile başlayan eserin ilk beyti şudur:

$2^{\mathrm{a}}$ İbtidâ Hak bu cihânı yok iken var eyledi İns ü cinni cümle mahlûkātı iẓhâr eyledi

Sonu:

69 ${ }^{\text {b }}$ Kerem-i 'avn-i Hudâ ile müyesser old 1 Didi Şevkīi bunı ahbâba te'lîf ideyim

Eb'adı (Dış-İç): $225 \times 165,175 \times 112 \mathrm{~mm}$ Satır Sayısı: İlk sayfa 11, diğer sayfalar 15 satırdır. İlki hariç her sayfa 2 sütuna ayrılmıştır.

Beyit sayısı: 1886

Telif Tarihi: Mukaddimede verilen tarih: 1263/ 1846-7

Istinsah Tarihi: Yok

Müstensih: İsmâil Vecdî el-Âmidî

Hat: Ta'lik. Nüshanın son sayfası (Derbeyân-1 Sebeb-i Nazm-1 in-Kitâb ve istinsah kaydının bulunduğu $69^{\text {b}}$ ) rikadır.

Kâğıt: Krem rengi, orta kalınlıkta ve âharsızdır. Başlıklar kırmızı mürekkeple yazılmıştır.

Cilt: Mukavva kapağı ebru desenlidir. Cilt sırtı kırmızı bezdendir.
Millet Kütüphanesi, Ali Emîrî Manzum, nr. 866: İstihsah tarihi bulunmas1 sebebiyle bu nüsha esas alınmıştır. ${ }^{3}$

Başr:

1'bl-Hamdu li'llâhi'llezîi zâde Mescide'lAkṣâ șerefen lâ-siyyemâ bi-ḳudûmihi ileyhi Seyyidü'l-halḳi ve'l-beşer... şeklinde mensur bir mukaddime ile başlayan eserin ilk beyti şudur:

$2^{\mathrm{a}}$ İbtidâ Ḥaḳ bu cihânı yoḳ iken var eyledi İns ü cinni cümle mahlûkātı ịhâr eyledi

Sonu:

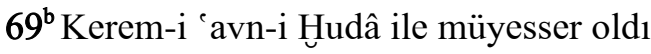
Didi Şevḳi bunı aḥbâba te'lîf ideyim

Eb'adı (Dış-Içc): 230 x 165, 182 x $120 \mathrm{~mm}$ Satır Sayısı: İlk sayfa 9, diğer sayfalar 15 satırdır. İlki hariç her sayfa 2 sütuna ayrılmıştır.

Beyit sayısı: 1887

Telif Tarihi: 1263 / 1846-47

İstinsah Tarihi: 1266 / 1849-1850 mâh-1 Şevvâl

Müstensih: İsmâil Vecdî el-Âmidî

Hat: Nesih

Kâğıt: Beyaz, ince, aharlı ve su yollu, filigranlı Avrupa kâğıt. Başlık ve cetveller kırmızı mürekkeple yazılmıştır.

Cilt: Mukavva kapağı ebru desenlidir. Cilt sirtı kırmızı bezdendir.

\footnotetext{
${ }^{3} \mathrm{Bu}$ nüsha A diğeri $\mathrm{B}$ nüshası olarak adlandırılmıştır. Makalede verilen örnek beyitler nüsha karşılaştırması sonucu hazırlanan metne göre numaralandırılmıştır.
} 


\section{Eserin Sebeb-i Te'lîfi}

Teşvîku'l-Müștâk ve Teşrîkun li'l'Uşşâk' in yazilma sebebi, eserin sonundaki "Der-Beyân-1 Sebeb-i Naẓm-1 în-Kitâb" başlığı altında şu şekilde ifade edilmektedir:

1. Sebeb-i naẓm-ı kitâbı size tasnnif ideyim Bilesiz anı yedi beyt ile te'liff ideyim

2. Yürüdüm Şâm-1 ŞSerîf'den țalebim Kuds-i Şerîf Diledim cân u dil[i] ol yere teklîf ideyim

3. İdüben anı ziyâret gerü geldim Şâm'a Ki didim göňlümü maḥbûblara teşfif ideyim

4. Var idi anda bir ahbâb-1 'azîzim geldi Ben anın hulk-ı cemilin nice ta' rîf ideyim

5. Baňa bin̆ dürlü edâ nâz ile ibrâm itdi Didi bildir baňa Kuds'ü aňa teşrîf ideyim

6. Tayanup ḳvvet-i bâzûya didim bismillâh Diledim hâțtr-ı pür-nûrunu taltîif ideyim

7. Kerem-i' 'avn-i Hudâ ile müyesser oldı $\left(69^{b}\right)$ Didi Şevk̄ī bunı ahbâbıma te'lîf ideyim

Yukarıdaki manzumede Abdurrahman Şevkî, Kudüs ve Şam'a yaptığı ziyaretlerin gözlemlerini "dostlarının arzusu ve 1srarı üzerine" yazdığını söylemektedir.

Ayrıca Şevkî, eserin ara beyitlerinde de kitabı kaleme almasındaki sâikleri aktarmıştır:

\section{Bu kitâbı nazm kılmaktan murâd} Kuds'ün̆ ạ̣vâli olunmak bunda yâd (3a)

Şâir bu beyitte kitabı yazmasının asıl nedeninin Kudüs'ü anlatmak olduğunu vurgulamaktadır.

\section{Su'âl eylerse ahbâbım kitâbın̆ 'illet-i nazmın Fakat Ş Sevk̄̄ riżâ-yı Hażret-i Rabbü'l-enâm ister \\ $\left(34^{2}\right)$}

beytinde ise kitabı Cenâb-1 Hakk'nn rızâsını kazanmak için yazdığını ifade etmektedir.

\section{Eserin Muhtevâs1}

Eserin konusu giriş bölümünden anlaşıldığ 1 üzere Mekke, Medîne, Kudüs ve Şam'ın faziletleri hakkındadır.

İslâm telif geleneğinde olduğu üzere mensur bir hamdele ve salvele ile başlayan eser, Allah Teâlâ'nın kâinatı ve insanoğlunu yaratma hikmetini birtakım nasihatlar eşliğinde ifade eden misralarla devam eder. Cenâb-1 Hak kulları için rahmetini arayıp bulmalarına yardımcı olacak mübarek mekânlar yaratmıştır. Yeryüzündeki bu bazı mukaddes mekânların yer aldığı şehirler olan Mekke, Medine, Kudüs ve Şam kısaca anlatılır ve kitabın yazılmasındaki asıl maksadın Kudüs'ü tanıtmak olduğu açıklanır:

9. Anlar içün ḳılmışam nice makāàm Key mu'azzamdır ḳılalar ḩoş ḳyâm

10. Ol mübârek yirlere kim geliser Şöyle bilsün rahmetimi bulısar

11. Yeryüzünde kılmadım așla ulu İsbu yerlerden begààyet sevgilü

12. Gerçi her kanda 'ibâdet itseler Eylerem rahmet ki kanda gitseler

13. Lâkin ol yerleri mahșûs ḳılmışam Dört kitâb içinde manșûs ḳılmışam

14. Biri old1 Mekke yerler efdali Raḥmetimle ânı ḳıldım müncelî

15. Kullara dârü' 'l-emân itdim ânı Şübhesiz bâğ-ı cinân itdim ânı

16. Her kim ânı yedi kez eyler țavâf Oddan âzâd olısar bî-ihtiliâf 
$3^{a} A$

19. Biri dahi ol Medîne şehridir
Yedi iklîm ol 'arûsuň mihridir

$3^{a} B$

20. Cünki 'âlem fahri Sulțân andadır

Andadır maḥbûb-ı Sübḥân andadır

21. Enbiyâlar ser-firâzı andadır

Bâg-1 Ku Kuds'ün̆ şâhh-bâzı andadır

22. İki 'âlem pâdişâhı andadır

Cümle mahlûkuñ penâhı andadır

23. Andadır nûr-i Muhammed Muștafâ

Andadır maḥşer güni sâhhib-livâ

24. Ey ki aňa ümmet olan gel berü

Ey sezâ-yı rahmet olan gel berü

25. Lâyı̣k oldı tâc-1 'izzet başın̆a

Ķondı şeksiz mürğ $-i$ devlet başın̆a

26. Birisi dahi mübârek Şâm imiş

Her kişiye vâcibü'l-ikrâm imiş

\section{Ol mübârek belde bir ḩoş beldedir \\ Vaṣfi dâ'im söylenür her dildedir}

On bâb hâlinde yazılmış kitabın birinci bâbında mezkûr şehirlerin ilk kez var edilişi, ikinci bâbında Şam'ın ve sakinlerinin medhi yer alır. Üçüncü ve dördüncü bâblarda söz Kudüs'e getirilerek Hz. Dâvûd ile $\mathrm{Hz}$. Süleyman'ın Mescid-i Aksâ'yı inşası tasvir edilir. Beş ve altıncı bâblarda bu bölgelerde bulunan nesneler tasvir edilir. Yedinci bâbda Sahratullah'ın sirları, sekizincide Kudüs ve Şam'daki kabristanları, son iki bâbda da bu mukaddes yörelerde medfun büyük zatların ziyaretgâhları anlatılır. Bu şehirlerin sâir beldelere üstünlükleri anlatıllrken ilgili ayet ve hadislere telmihlerde bulunulmuş, İslâm tarihinden birtakım hâdiseler ile başta Mi'râc olmak üzere bazı mucizeler aktarılmıştır.
Kitabın neredeyse üçte birini oluşturan birinci bâbda, Mekke, Medîne ve Kudüs'ün yaratılışı anlatılmış ve bu bölgelerin kiymetlerini Mekke'de Kâbe-i Muazzama'nın, Medine'de Hz. Peygamber'in mübârek mescidinin ve kabr-i şerifinin, Kudüs'te ise Beytü'l-Makdis'in bulunmasından aldığı eklenmiştir. Bununla beraber Kudüs şehrinin tüm enbiyâya kıblegâh olması ve Mi'râc hâdisesinin gerçekleştiği makam olması hasebiyle ayrı bir kıymeti bulunduğu belirtilmiştir. Hz. Peygamber'in Mi'râc mucizesinde müşahede ettiği hadise ve nesnelerden başlayarak yeryüzüne dönüşüne kadar başından geçenler ayrıntılı biçimde aktarılmıştır. Yine bu bölümde yer ve göğün Hz. Peygamber'in varlı̆̆1 üzerinden çekişme ve kıskançlık içerisinde bulundukları sembolize edilmiştir. $\mathrm{Bu}$ beyitler ayet ve hadislerle desteklenmiştir:

Sübhânelležî esrâ bi-'abdihî leylen mine'lMescidi'l-Ḥarâmi ile'l-Mescidi'l-Akṣa'lležî bâreknâ ḥavlehû ${ }^{4}$

\section{$\left(5^{\mathrm{a}} \mathrm{B}\right)$}

17. Çünki tenzîh itdi sübhâne'llezî didi Hudâ Kendü zâtın̆ her nakāàyșdan mu'arrâ bî̀ğubâr

18. Ya'ni mahbûbın̆ harem-gâhından indi bir gece Da'vet ol semt-i diyâr-1 Mescid-i Akṣấ'ya sâr

19. Şöyle Akṣâ kim mübârek ḳıldı her bir çevresin Dahi pür-nûr eyleyüp kıldı aňa pek i' tibâr

\footnotetext{
${ }^{4}$ İsrâ suresi, 17/1; "Bir gece, kulunu Mescid-i Harâm'dan, çevresini mübarek kıldığımız Mescid-i Aksâ'ya götüren Allah, noksan sıfatlardan münezzehtir."
} 
Ayrıca yine bu bölümde şeriat, tarikat, hakikat ve marifet kavramları üzerine beyitler yazılmış, ehl-i tasavvufun bu dört kavram üzerine söylemiş olduğu tariflerden örnekler verilmiştir:

1. Şerî atle kişi mâhir degilse

Țarîkatden esser bilmez dimişler

Dahi bilmezse ol kişi tarîkat

Hakikatden haber bilmez dimişler

2. Şerî̀ atle çün ebhâar olmayanlar

Tarîkatle pür-envâr olmayanlar

Hakikatden haberdâr olmayanlar

Gelür böyle gider bilmez dimişler

$\left(18^{a} A\right)$

3. Şerî̀ atdir kişiniň her esâsI

Buňa itmek gerekdir iltimâsı

Eger olmazsa dâyim âş̧inâsı

Kalur ol derbeder bilmez dimişler

Yukarıdaki dörtlükler ve bağlamında tasavvufun esası kabul edilen şeriat, tarikat ve hakikat anlatır, bu üçünün birbirleri için gerekliliği ve zorunluluğu ifade edilir.

Çeşitli ayetlerden iktibaslar ile onların manzum şerhini yapan Abdurrahman Şevkî, İslâm kültüründe genel kabul gördügüü üzere, Tîn suresinden yaptığı alıntılarda ilk ayetteki "Tîn" lafzıyla Dımaşk bölgesine, "Zeytun"la Kudüs'teki Zeytin Dağı'na, “Beledü'lEmîn"le ise Mekke şehrine işaret edildiğini ifade etmiştir. Yer yer Kudüs'ün ve Kâbe'nin özelliklerini ve diğer tüm beldelerden üstün, temiz ve farklı oluşunu nazmederek bu bâbı tamamlamıştır:

290. Hażret-i Ebû Hureyre söyledi

'An Resûlillâh rivâyet eyledi

291. Haḳ te'âlâ hażreti dünyâda hem

Dört maḥal vardır an̆a itdi ḳasem
Anları yâd itdi Kur'ân içre ol

Nitekim tenzîl-i Furkāan içre ol

$21^{a} A$

Ve't-tîni ve'z-zeytûni ve țûr-i sînîne ve hâzę'lbeledi'l-emîn ${ }^{5}$

293. Didiler ve't-tîni lafżından murâd

Çün Dımaş̧k’ın țag̀ına virdiler ad

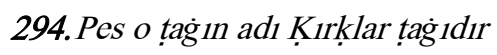

Çevresi gülzâr-1 cennet bâğ $1 d ı r$

$21^{a} B$

295. Dahi medḥ-i Şâm saňa ta'rîf olur

Sabr ḳl vașfi mahallinde gelür

Ve'z-zeytûni

296. Dahi ve'z-zeytûni ol râvî didi

Kuds'üň etrafinda bir țaġın adı

Ve țîr-i sînîn

İkinci bâb "Şâm-1 Şerif'in faziletlerini beyan eder" başlığını taşımaktadır. $\mathrm{Bu}$ babta bölgenin, Şam ismini, Kâbe'nin şimalinde bulunmasından aldı $\breve{g}_{1}$ hatırlatılarak, $\mathrm{Hz}$. Peygamber'in Şam'1 övgüsü sebebiyle meleklerin gece gündüz bu şehrin semalarında bölgeye ve ehline rahmet dileyerek uçtuğu anlatılmıştır. Akabinde Allah Teâlâ'nın yeryüzü için on nimet yarattığ 1 ve bunların dokuzunu Şam'a ayırdığı, yine yarattığ 1 on şerden birini Şam'a, dokuzunu diğer beldelere dağıttığı rivayeti aktarılmıştır. Şam'ın faziletlerini zikreden hadisler verilerek bu hadislerin manzum şerhi yapılmıştır. Ayrıca içi dışı evliya dolu ve havası suyu latif Şam mübalağalı şekilde medhedilmiştir. Yine bu bâbda Resûlullah'ın zevceleri ile Şam'da medfun Bilâl-i Habeşî, Ubeyy ibn-i Ka'b, Hazret-i Ebü'd-Derdâ, Hazret-i Talha, Bayezid-i Bistâmi başta olmak üzere toplam 22 zâtın kabrine işâret edilmiştir. (Abdurrahman ibn-i Ebû Bekr es-Sıddîk,

\footnotetext{
${ }^{5}$ Tûr suresi, 95/1-3; “İncire, zeytine, Sina dağına ve şu emin beldeye yemin ederim ki..."
} 
Abdullah ibnü's-Selâm, Hz. Dihyâ, Hz. Sancakdar, İmâm Zeyne'l-Âbidîn, Sitti Zeyneb bint-i Ali, Sitti Rukiyye bint-i Ali, Şeyh Muhyiddînü'l-Arabî, İmam Fahru'rRâzî, Şeyh Reslân, Ebû Müslim el-Havlânî, Abdulganiyyi'n-Nablûsî, Ebû Süleymân-1 Dârânî, Behlûl-i Dânâ, Nûreddin eş-Şehîd, Velîyyullâh Ayağı Panbuklu Dede). Şam'da, duaların makbul olduğu bazı mekânlar bildirilerek bölüm tamamlanmıştır.

415. Didi Beytü'l-Makdis'i Sâm ibn-i Nûh İbtidâ ol yapup itmişdi fütûh

416. Șoňradan Sulțân Süleymân geldi çün Ol binânın̆ üstünü kıldı bütün

417. Ezrakī’den naḳl olunur bir kelâm İbtidâ Allâhu Kuddûsü's-Selâm

418. Ka'be'niň yirini halk itdi hemân Yok idi așlâ ne kevn ü ne zamân

419. Cümle eşyâdan iki biň yil selef Ka'be'niň ḳıldı yerini pür-şeref

Üstteki beyitlerin de yer aldığı üçüncü bâb Hz. Davud ve Hz. Süleyman'ın Mescid-i Aksâ'y1 inşâs1 üzerinedir. Kâbe ile Mescid-i Aksâ arasındaki zaman farkı, Kâbe'nin Hz. Nûh tufanında yıkılması, Hz. İbrahim ve Hz. İsmail tarafindan yeniden yapilması bu bölümde anlatılan konulardandır.

Dördüncü bâb Abdulmelik ibn-i Mervan'ın Mescid-i Aksâ'yı tamirinin anlatıldığ bölümdür.

Beşinci bâb Kudüs'te bulunan hayranlık uyandırıcı güzellikler, altıncı bâb Mescid-i Aksâ'da namaz kılmanın ve sâir ibadetin sevabının çokluğu üzerinedir.
Fîhimâ 'aynâni tecriyân

2. Birisi Busyân pın̆arıdır biri Sulvân dimiş Kuds 'ün̆ ețrafinda dutmuş bunun ikisi vațan

Fîhimâ 'aynâni nażżăhatân?

3. Birisi 'Akke pın̆arıdır biri Zemzem șuyu Bunları arzû iderler Hind ile ehl-i Yemen

Yukarıda ayetlerle desteklenmiş bu mısraları içeren yedinci bâbta Sahratullah ve onun altından çıkan sular (Busyân, Sulvân vb.) ile bölgeye nüzûl eden melekler anlatılırken, sekizinci bâbda Kudüs'teki ziyâret mahalleri ve burada medfun kimseler tanıtılmıştır.

Dokuzuncu bâbta Kudüs'e gelen peygamberler ve ashabından, onuncu bâbta da Hz. İbrâhim ve onun aile efradının kabirlerinden bahsedilmiştir.

Son olarak, şâir gördüğü mukaddes beldeleri tasvir etmiş olmaktan duyduğu mutluluğu ve şükrü ifade ederek, bir münâcaat ve bir sebeb-i telif manzumesi ile eserini tamamlamıştır.

Teşvîku'l-Müştâk ve Teşrîkun li'l-'Uş̧̧âk konusu itibariyle İslâmi kaynakların yoğun şekilde kullanıldığ 1 bir eserdir. Kitapta Hz. Muhammed'in hayatına, yaşadığı mukaddes coğrafyaya ve mucizelerine yer verilmiştir. Dolayısiyla eserde ayet ve hadislerin doğrudan veya dolaylı olarak yer alması tabiîdir. Metinde bir kısım evliyâ ve enbiyâdan bahsedilmesi, İslâm coğrafyasının mübârek beldelerinden daima önemli sayılan dört bölge (Mekke, Medine, Kudüs, Şam) üzerinde durulması, muhtevâ oluşturulurken Kur'an ve Sünnet'ten başka tarih, siyer ve coğrafyadan da istifâde edildiğini göstermektedir.

\footnotetext{
${ }^{6}$ Rahman suresi, 55/50; "İkisinde de akıp giden iki kaynak vardır."

${ }^{7}$ Rahman suresi, 55/66; "İkisinde de durmadan fışkıran iki ırmak vardır."
} 
Çeşitli mekânların (şehir, ülke, mescid vb.) övülmesi veya yerilmesi hakkında hadis kaynakları ve şehir tarihlerinde pek çok zayıf rivayet bulunmaktadır. $\mathrm{Bu}$ tür rivayetlerin ortaya çıkmasında bazı siyasi, sosyal ve ekonomik sebeplerin bulunduğunu daha evvel de belirtmiştik. Meşhur hadis kitaplarında yer alan, hatta Mekke ve Medine şehirlerini de içine alan fezâil türü bu rivayetler incelendiğinde, mezkûr sebepler fark edilebilecektir (Ünal 2000: 67-90). Hadis ilminde, sıhhati açısından ister sahih ister zayıf kabul edilsin, içerikleri ve ifade biçimleri birbirine benzeyen bu fezâil hadisleri ile yapilan iktibas ve telmihlerin eserde ne şekilde yer aldığı da incelenmiştir. Netice itibariyle bu rivayetler bizi her zaman bir hadis metnine ve kaynağına götüremedi. Yani bu ve benzeri ifadelere ne sahih ne de mevzu hadis kaynaklarında rastladık:

"Men furiża 'aleyhi'l-hacce felem yehic felyemut in şâe yehûdiyyen ve in şâee nașrâniyyen" $\left(44^{\mathrm{b}}\right)$

"Lâ-tüşeddü'r-rihâlu illâ ilâ șelâs: Mescidî ve Mescidi'-Harâm ve Mescidi'l-Akṣâ" (52 $\left.{ }^{\mathrm{b}}\right)$

"Men erâde en yenžura ilâ buḳeatin min buk 'i'l-cenneti fel-yenzur ilâ Beyti'lMukaddes" (66 $\left.{ }^{\mathrm{a}}\right)$ gibi.

\section{Eserin Dil ve İmlâ Özelllikleri}

XIX. asrın ikinci yarısında kaleme alınan Teşvîku'l-Müştâk ve Teşrîkun li'l- 'Uşşâk son dönem Osmanlı dil özelliklerini taşısa da aşağıda örneklendirileceği üzere bazı arkaik kullanımlar içermektedir.

Farklı vezinlerin kullanıldığı, yer yer kaside, gazel, murabba ve mesnevîlerin yer aldığ eserde dil ekseriyetle sadedir.

Mevcut iki nüshanın birbirinden veya aynı bir başka nüshadan istinsah edildiği düşünülmektedir. Aynı müstensihin elinden çıkan bu iki nüshanın hataları da birbiriyle örtüşmektedir.
Ana nüsha kabul ettiğimiz metin yer yer harekelenmiştir. Harekelemelerde istikrar yoktur.

Başlıklar Farsça, Arapça ve Türkçe yazılmıştır. Hadislerin ara başlık gibi, kırmızı mürekkeple yazıldığı pek çok bölüm vardır.

Eserde bazı kelimelerin sonunda bulunmas1 gereken $-1 / \mathrm{i}$, -a/e gibi hâl ekleri ihmâl edilmiştir.

Ayrıca sağır kâf (nazal nûn) harfinin yazımında tutarlılık yoktur. Sağır kâf olması gereken yerlerde nûn harfinin veya nûn harfinin bulunması gereken yerlerde sağır kâfın kullanıldığı görülmüştür. Tamlama geçişlerinin ve "bağlaç vavı"nın kullanımında da çok sayıda ikilem ve hata vardır. Terkip $-\mathrm{i}$ 'leri kimi yerlerde ye (ى) harfi ile ifade edilmiştir. $\mathrm{Bu}-\mathrm{i}$ 'ler bazen de esre ile gösterilmiştir.

Farsça "hoca" kelimesi yaygın imlâdan "خوجه" farkl1 şekilde birkaç yerde (خواجه) şeklinde yazılmıştır.

Metnin 686. ve 687. beyitlerinde yer alan "göründiser" ve "kavisar" kelimelerinden ilkinde -di'li geçmiş zaman ekinin, -ser ekinden sonra kullanılması gerekirken aksi mevcuttur. -di ekinin kaldırılmas1 durumunda anlamlı hale gelebilecek bu kullanım, arkaik şekline dahi rastlamadığımız nadir örneklerdendir. "kavısar" (قاويسر) kelimesi ise kullanıldığ 1 yer itibariyle "kovmak" şeklinde tercüme edilmeye müsaittir ve nadir bir kullanım olmas1 sebebiyle buraya eklenmiştir.

Ayrıca eserde Eski Anadolu Türkçesine ait baz1 kullanımlar mevcuttur. "bulavuz", "geliser", "bilevüz" gibi. 
Bazı kelime sonlarındaki hal eki -i'den evvel gelen kaynaştırma harfi "ye"nin üzerine esre harekeli bir hemze yazmıştır. Örnek olarak şunlar verilebilir: Mustafâ'[y]1, "Kâbe'[y]i", "Sahrâ'[y]1", "belde[y]i" gibi.

Telmih ve iktibasın çok sayıda örneğini barındıran eser, bu yönüyle güçlü kabul edilebilir.

Eser Türkçe, Arapça ve Farsçanın üçünün de kullanıldığ 81 bölüm başlığı içermektedir. 1887 beyitten oluşan eserde çeşitli nazım şekilleri kullanılmıştır. Eserin bütününde hâkim olan 1034 beyitlik bir ana mesnevi vardır. Bu mesnevi yer yer kaside, gazel ve murabbalar ile örülmüştür. Mesneviden sonra en fazla, kaside ve gazel kullanılmıştır. Bunların yanı sıra eserde kıt'a, murabba, üç beyitli manzumeler ve bir adet müseddes-i mütekerrir yer almaktadır:

1. Innâyet bahşs idüp ol Hażret-i Mevlâ bu gümrâhı Kıllupdur cânib-i Kuds-i Şerîf'e ben dili râhî Nice biň cilve-i esrârnnuň oldum ben âgâhı Cihânın̆ çeşmime bir zerre gelmez 'izz ile câhı Çeküp endîşe-i hasret ḳlurken zâr nâgâhî Bi-ḥamdillâh müyesser oldı görmek Sahratullâh'ı

$\left(68^{a}\right)$

Kudüs'ü ziyaret kendisine nasip olan Şevkî'nin eserdeki tek müseddesine âit ilk bent yukarıda örnek verilmiştir. Burada olduğu gibi duâ, şükür ve temenni üslubu eserin geneline hâkimdir.

Ayrıca eserde üç beyitli manzumeler olarak adlandırılmaya uygun 22 bölüm bulunmaktadır.

Ahenk unsurlarının en önemlilerinden olan kafiye yönüyle başarılı bulunan eser aruzla yazılmıştır. Yer yer kusurlara rastlansa da geneli itibariyle aruzun başarılı biçimde uygulandığı görülmektedir. Eserde kullanılan aruz kalıpları şunlardır:
1. Remel bahri: "Fâ'ilâtün Fâ'ilâtün Fâ'ilâtün Fâ'ilün", "Fâ'ilâtün Fâ'ilâtün Fâ'ilün", "Fe ilâtün $\mathrm{Fe}$ 'ilâtün $\mathrm{Fe}$ 'ilâtün $\mathrm{Fe}$ iliün"

2. Hezec bahri: "Mefầîlün Mefầîlün

Mefâ‘îlün Mefầîlün”, “Mefâ‘îlün Mefầîlün $\mathrm{Fe}$ 'ûlün”, "Mef'ûlü Mefầîlü Mefầîlü Fe'ûlün”

3. Muzari bahri: "Mef'ûlü Fâ'ilâtü Mefâ 'îlü Fâ'ilün”

\section{Sonuç}

İlk örneklerini Arap edebiyatında gördüğümüz faziletnâme türünün tanımı ve kapsamı üzerinde durulmuş, Türkçe yazılmış manzum/mensur ve telif/tercüme/teliftercüme faziletnâme örneklerine yer verilmiştir.

Özelde şehir faziletnâmelerini ele alan bu çalışma hazırlanırken şehirler üzerine yazılan türlerin çeşitliliği dikkat çekmiştir. Yalnızca şehir fezâili ve şehir tarihçiliği değil, aynı zamanda şehrengizler, seyahatnâmeler ile fetihler dolayısıyla yazılan fetihnâmeler ve düşman eline geçen şehirlere söylenen mersiyelere varıncaya dek eserler verildiği tespit edilmiştir. Şehir faziletnamelerinin geniş muhteva çerçevesiyle şehrengiz, seyahatname, bilâdiye vb. diğer bazı türlerden ayrıldığ görülmüştür.

Şehir faziletnâmesi, seyahatnâme ve şehrengiz türü eserler özellikle şehir tarihçiliği ve sosyal tarih konusunda yapılacak çalışmalara kaynaklık edebilir.

XIX. yüzyıla âit Teşvîku'l-Müştâk ve Teşrîkun li'l-'Uşşâak adlı Mekke, Medine, Kudüs ve Şam şehirleri faziletnâmesi üzerine yaptığımız inceleme neticesinde "Şevkî" mahlaslı müellif Abdurrahman Şevkî hakkında birkaç bilgi sunulmuştur. 
Şevkî'nin faziletnâmesi Teşvîku'l-Müsstâk ve Teşrîkun li'-'Uşşâk muhtevâsı itibariyle emsalleriyle benzerlik gösterse de telif ve manzum oluşuyla diğerlerinden ayrılmaktadır. Manzum oluşunun yanısıra samimi üslûbu eserin değerini artırmaktadır.

\section{Kaynakça}

Abdurrahman ed-Dımaşki el-Hanefi ibn Abdürrezzak. (1995). Hadâiku'l-in 'âm fifezâ'ili'ş-Şâm. (thk. Yusuf Bedivî). Dımaşk. Abdurrahman ed-Dımaşki el-Hanefi ibn Abdürrezzak. (t.y). Terceme-i Hadîkatu'lEnâm fi-Fezâ'ili'ş-Şâm. (trc. Abdurrahman Şevkî). Millet Ktp., Ali Emîrî Tarih. nr. 905.

\section{Abdurrahman Şevki. (1263/1846-7).} Teşvîku'l-müşâk ve teşrîkun li'l-'uşşâk. Millet Ktp., Ali Emîrî Manzum. nr. 865, 866. Abdülbaki, Muhammed Fuad. (1994). elMu'cemü'l-müfehres li-elfâzi'l-Kur'ân. Kahire.

Aça, Mehmet \& Gökalp, Haluk \& Kocakaplan, İsa. (2009). Başlangıçtan günümüze Türk edebiyatında tür ve şekil bilgisi. İstanbul: Kriter Yayınları.

Ahmed Fakih. (1974). Kitâbu evsâf-1 mesâcidi'ş-şerife. (yay. Hasibe Mazıoğlu). Ankara: Türk Dil Kurumu Yayınları.

Ahsasî, Ahmed. (2006). Erbaûne hadîsen fî fezâ'ili'l-Medîneti'l-Münevvere. (thk. A. Abdullah Bacur Ali). Kahire.

Aydın, Mehmet. (1987). Fezâ'il-i Mekke ve'l-Medîne ve'l-kudsi Şerif. Yayımlanmamış yüksek lisans tezi, Gazi Üniversitesi Sosyal Bilimler Enstitüsü, İzmir.

Çelebioğlu, Âmil. (1971). Süleyman Nahîfî ve Fazîlet-i Savm (Zuhrü'l-Âhire) adlı eseri. Diyanet İşleri Başkanlı̆ğ Dergisi. X, s. 342343.
Çelebioğlu, Âmil. (1994). Kanûnî Sultan Süleyman devri Türk edebiyatı. Ankara: Milli Eğitim Bakanlığı Yayınları.

Dadaş, Cevdet. (1995). Bâkî, Fezâ'il-i Cihâd. Yayımlanmamış doktora tezi, Trakya Üniversitesi Sosyal Bilimler Enstitüsü, Edirne.

Güzel, Abdurrahman. (2006). Dinî-Tasavvufî Türk edebiyatı. Ankara: Akçağ Yayınları.

Hıfzî. Tarîh ve fezâ'il-i Kuds-i Şerif. Bayezid Devlet Ktp., nr. 507.

Hıfzî. (1265). Tarîh ve fezâ'il-i Kuds-i Şerif, Dârü't-tıbâati'l-Âmire: İstanbul.

İbn Hazm. (1968). Fezâ'ilü'l-Endelüs ve ehliha. (haz. Selahaddin el-Müneccid). Beyrut: Dâru'l-kitâbi'l-cedîd.

İbn Manzur. (1997). Lisânu'l-'Arab. Beyrut: Dârü'l-ihyâi't-türâsi'l-Arabi.

Kandemir, Mehmet Yaşar. (1991). Mevzu hadisler: menşei, tanıma yolları, tenkidi. Ankara: Diyanet İşleri Başkanlığı Yayınları.

Kandemir, Mehmet Yaşar. (1995). Fezâil. Türkiye Diyanet Vakfi Íslam ansiklopedisi içinde (C. 12). İstanbul: Türkiye Diyanet Vakfi Yayınları.

Kırman, Aydın. (2004). Yemînî’nin Fazîletnâme'si (şekil ve muhtevâ tahlili). Yayımlanmamış doktora tezi, Ege Üniversitesi Sosyal Bilimler Enstitüsü, İzmir.

Levend, Agah Sırrı. (1973). Türk edebiyatı tarihi. Ankara: Türk Tarih Kurumu.

Râğıb el-Isfehânî. (2002). Müfredâtu elfâzi'lKur'ân. Beyrut: ed-Dâru'ş-Şâmiyye.

Rıfâî, Said. (1992). el-Ehâdîsü'l-vâride fî fezâ'ili'l-Medîne. Medine. 
Sancakl1, Saffet. (2001). Surelerin faziletiyle ilgili bazı tefsirlerde yer alan Apokrif hadislerin kritiği. İslâmî Araştırmalar Dergisi, 14/1, 133.

Sezen, Tahir. (2006). Osmanl yer adları, Ankara: Başbakanlık Devlet Arşivleri Genel Müdürlügü.

Şeşen, Ramazan. (1998). Müslümânlarda tarih ve coğrafya yazıcılığı: başlangıçtan $X I X$. yüzyılın sonuna kadar. İstanbul: İslam Tarih, Sanat ve Kültürünü Araştırma Vakfı.

Tepeli, Yusuf. (2002). Derviş Muhammed Yemînî, Fazilet-nâme; giriş, inceleme, metin, gramatikal dizin. I-II. Ankara: Türk Dil Kurumu.

Tergip, Ayhan. (2010). Bâkî'nin Meâlimu'lyakîn adlı eseri üzerinde dil incelemesi (metin-sözlük). Yayımlanmamış doktora tezi, İstanbul Üniversitesi Sosyal Bilimler Enstitüsü.

Ünal, İsmail Hakk1. (2000). Şehirlerin faziletleriyle ilgili uydurma hadisler ve "Hayru'l-Buldân" risâlesi. Ankara Üniversitesi İlahiyat Fakültesi Dergisi. XVI, 67-90.

Yıldırım, Derya. (2010). Fezâyilü'l-Mekke ve'l-Medine ve'l-Kudüs. Yayımlanmamış yüksek lisans tezi, Celal Bayar Üniversitesi Sosyal Bilimler Enstitüsü, Manisa.

Y1lmaz, Fatih Mehmet. (2011). Türk Edebiyatı'nda Hz. Ebû Bekir vecizeleri ve Bedreddin b. Himmet-Yârü'l-Mevlevî'nin Tuhfetü's-Sıddîk'. Yayımlanmamış yüksek lisans tezi, Cumhuriyet Üniversitesi Sosyal Bilimler Enstitüsü, Sivas. 